JOURNAL OF ENGINEERING SCIENCES

ЖУРНАЛ ІНЖЕНЕРНИХ НАУК

ЖУРНАЛ ИНЖЕНЕРНЫХ НАУК

Web site: http://jes.sumdu.edu.ua

DOI: $10.21272 /$ jes.2019.6(1).f2

Volume 6, Issue 1 (2019)

UDC 631.371:620.92

\title{
Improvement of the Vacuum Cooling System for Biodiesel Production
}

\author{
Sharapov S. ${ }^{*}$, Starchenko M. ${ }^{1}$, Protsenko M. ${ }^{2}$, Panchenko V. ${ }^{1}$, Kovtun V. ${ }^{1}$ \\ ${ }^{1}$ Sumy State University, 2 Rymskogo-Korsakova St., 40007 Sumy, Ukraine; \\ ${ }^{2}$ Academy of Management and Administration in Opole, 18 M. Niedzialkowskiego St., 46020 Opole, Poland
}

\author{
Article info: \\ Paper received: \\ October 16, 2018 \\ The final version of the paper received: $\quad$ February 3, 2019 \\ Paper accepted online:
}

*Corresponding Author's Address:

s.sharapov@kttf.sumdu.edu.ua

\begin{abstract}
The article deals with the actual problem of improving the vacuum cooling efficiency systems during the biodiesel production by using vacuum devices account for the liquid-vapor ejector, which operates on the principle of jet thermal compression. The purpose of this study is the feasibility of using vacuum devices, that based on the liquid-vapor ejector, and takes as a basis the principle of jet thermal compression in vacuum cooling systems of biodiesel production units. This article describes the basic scheme of the cooling system devices during the biodiesel production, which includes a three-stage steam-jet ejector and the proposed scheme based on the liquid-vapor ejector. A comparative analysis of the vacuum cooling systems during biodiesel production units was realized, where the schemes were compared on the basis of existent three-stage steam-jet ejectors and a new single-stage vacuum unit based on a liquid-vapor ejector. An exergy method of assessing the effectiveness of the proposed equipment was used as a comparison, because in the working process there is a transformation of two energy types: electric for the pump drive and heat for heating the working fluid of the active flow in the exchanger-heater. The intermediate pressure between the liquid-vapor ejector and the liquid-ring vacuum pump can help to achieve the highest characteristics of the new technology on the optimization parameters.
\end{abstract}

Keywords: vacuum cooling system, liquid-vapor ejector, biodiesel production, exergy efficiency.

\section{Introduction}

At the present stage of industrial development of the European Union and North America countries, renewable energy sources are widely used, in particular, the replacement of traditional fossil carbon energy sources with products of plant and natural origin. A price increasing on oil and natural gas, poses a challenge to modern science to find environmentally friendly fuel, which would be a relatively cheap alternative to existing but would not pollute the environment.

In particular, biodiesel belongs to this sort that lately is becoming more widely used. Thus, in 2010, in the European Union countries for its production was about $6 \%$ of all fuel, and in 2020 this figure will increase to $20-25 \%$.

An integral part of the biodiesel production is the process of purification of its raw materials from odorants, which is carried out at a pressure below atmospheric pressure. The world's leading manufacturers still use multistage vacuum units based on steam-jet ejectors with intermediate condensers, often in combination with liquid-ring vacuum pumps, which are unproductive(only 2$10 \%)$.
Therefore, at this stage it is very important to use significantly liquid-vapor ejectors (LVE), which are based on the principle of jet thermal compression. These units are much more efficient due to a better workflow and can significantly simplify the design of the installation, as there is usually a single-stage.

\section{Literature Review}

The working process of the liquid-vapor ejector, which operates on the principle of jet thermal compression is quite complex, but today a more reliable technique has been obtained, which allows to determine its regime and geometric parameters as close as possible to reality [1].

The authors have successfully conducted theoretical and experimental studies and modeling the working process of the liquid-vapor ejector in the ANSYS CFX software package on different operating parameters of the pumped passive flow and various structural designs with the definition of achievable indicators of its efficiency [2-4], which are significantly higher than in similar steam. 
Also, the results of theoretical and experimental studies about the feasibility the using of the liquid-vapor ejector for other purposes, in particular, in the food, chemical and engineering industries [5].

To assess the energy efficiency of a vacuum unit based on the liquid-vapor ejector operation, the most correct method is to use the exergy method of thermodynamic analysis. Using this method makes it possible to uniquely express and distribute heterogeneous energy flows in thermomechanical systems.

Exergy evaluation of the perfection energomonitoringdegree in the vacuum system study is based on modern terminology and regulations that you laid in the works [6-8].

\section{Research Methodology}

\subsection{The basic diagram of a vacuum cooling system unit for biodiesel production}

A traditional installation of biodiesel production by "Körting" (Hanover, Germany) (Figure 1) is a multi-stage vapor vacuum system, which consists of two boosters (two large steam-jet ejectors, that are connected in series), the main mixing condenser, a small intermediate ejector with a mixing condenser for pumping air, as well as a water-ring vacuum pump of the final stage.

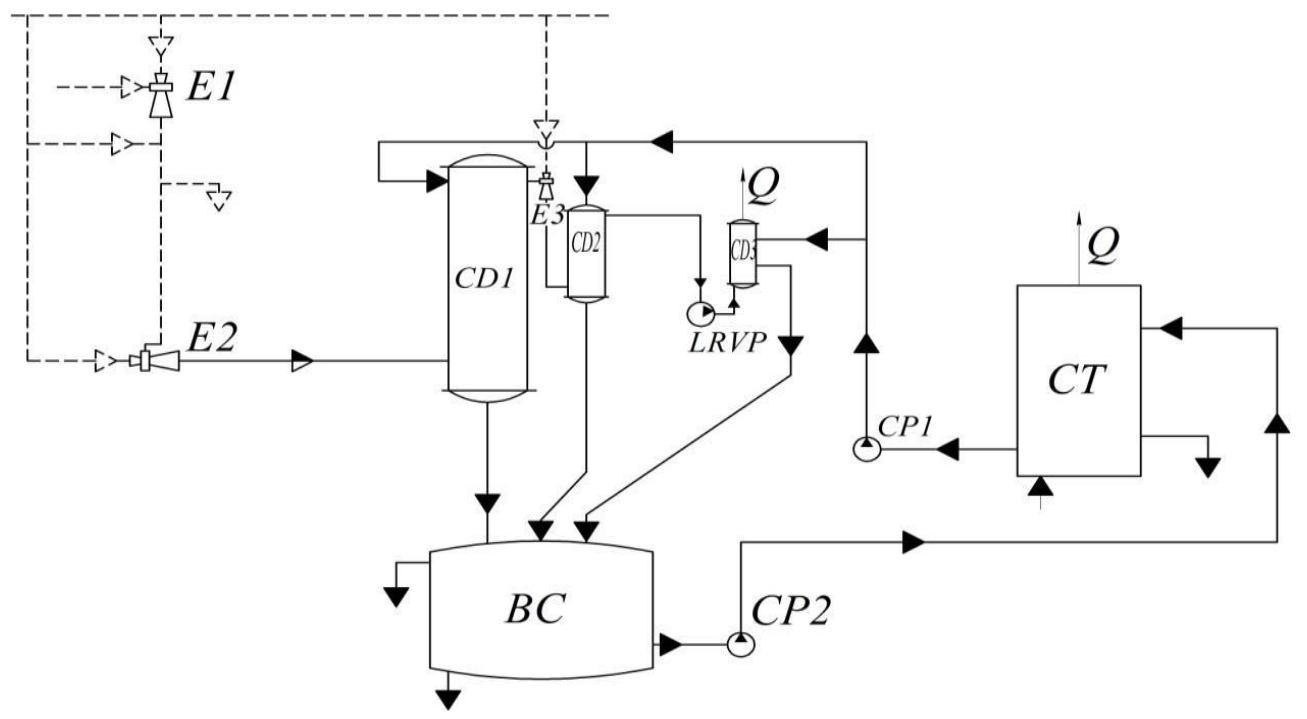

Figure 1 - The basic scheme of a vacuum cooling system unit for biodiesel production: LRVP-liquid ring vacuum pump; E1, E2, E3 - ejectors; CD1, CD2, CD3 - condensers; CP1, CP2 - coolant pumps; CT - cooling tower; BC - barometric capacity

The productiveness of the basic unit is $220 \mathrm{~kg} / \mathrm{h}$ of water vapor $8 \mathrm{~kg} / \mathrm{h}$ of air $5 \mathrm{~kg} / \mathrm{h}$ of free fatty acids. Deodorization technology involves the extraction of fatty acids (odorants) by bubbling hot water vapor through a processed fuel ball at a pressure of $2 \mathrm{kPa}$. Maintaining this level of vacuum increases the volatility of odorants and their vapors diffuse into water vapor bubbles.

The bubbling steam condensation and the pressure maintenance at a certain level is ensured by the supply of cooling water, which circulates in the cooling circuit through the cooling tower.

The working pressure of the boiler steam, that is used by the steam jet ejectors as the working jet of the active flow is 9 bar, the cooling water temperature at the inlet is $33 \mathrm{C}$.

The working steam condensate, that supplied to the nozzle of the active flow in steam-jet ejectors is polluted the components, which contained in the pumped flow with the bubbling steam and doesn't return to the unit. For surface-type capacitors, which are used in this unit, it is necessary to pump out the condensate, as the condensation pressure is less than atmospheric.

This type of vacuum systems combines the advantages, when steam-jet ejectors and water ring vacuum pumps are working together. This means, that the bubbled steam is compressed only by steam-jet ejectors (socalled boosters) to the first possible stage of condensation. And after the first stage, behind the main mixing condenser, combinations of steam-jet ejectors and water ring pumps are possible.

\subsection{A vacuum cooling system's scheme of biodiesel production unit, that is based on liquid-vapor ejector}

The alternative circuit solution, which is proposed (Figure 2), minimizes the consumption of boiler steam in the vacuum system. Pumping of the vapor-gas mixture is provided by a liquid-vapor ejector (LVE), operating as a part of the vacuum unit.A condenser unit is provided for the vapor phase condensation of the mixing flow after the separator and return the working fluid to the circulation circuit of the vacuum unit, including a condenser, a water ring vacuum pump and a cooling system for circulating water.

The use of a mechanical vacuum pump as a forvacuum unit in this case is advisable from the standpoint of ensuring higher energy efficiency of the vacuum system. 


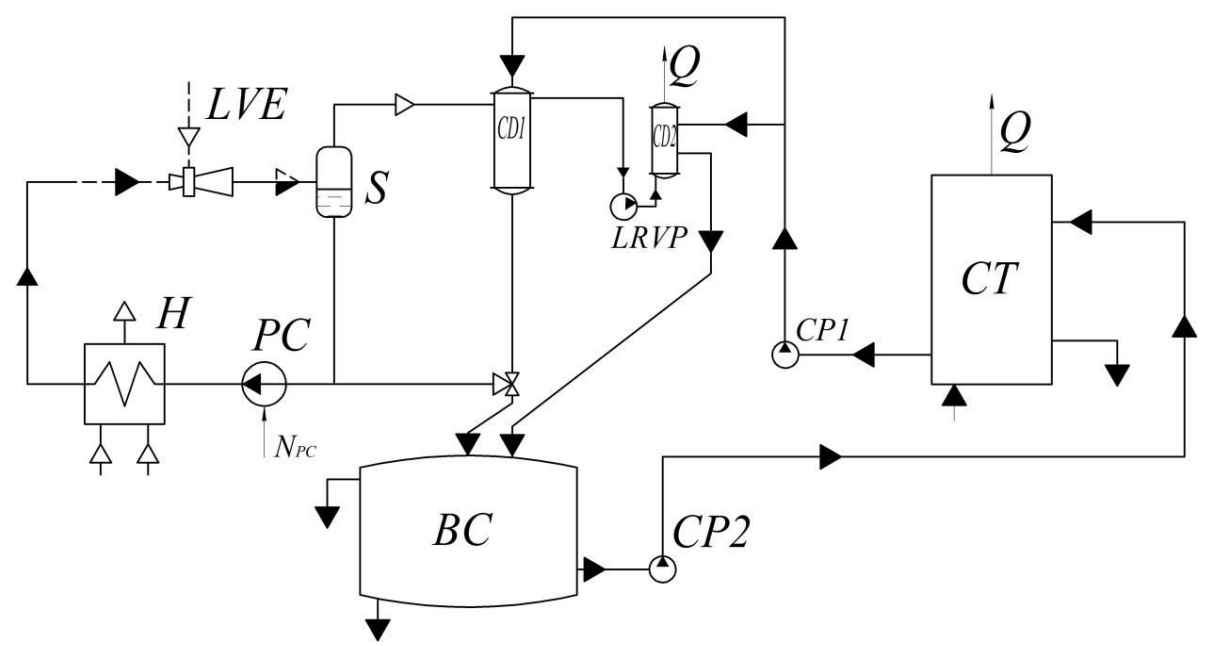

Figure 2 - A vacuum cooling system's scheme of biodiesel production unitbased on LVE: LVRP- liquid ring vacuum pump; LVE - liquid-vapor ejector; $\mathrm{H}$ - heater; PC - circulation pump; S - separator; CD1, CD2- condensers; CP1, CP2- coolant pump; $\mathrm{CT}$ - cooling tower; $\mathrm{BC}$ - barometric capacity

\subsection{An exergy analysis of new equipment effectiveness use}

An exergy analysis is executed with such step-by-step procedures:

- choose limits of the system;

- make a formalized scheme of exergy transformations in general and the system components;

- calculate the value of exergy flows crossing the system boundaries or components;

- perform classification of exergy flows in the categories, such as: "fuel", "product", "destruction", "loss";

- determine the indicators (criteria) of the exergy analysis;

- determine the optimization directions of the system as a whole or its individual components.

The scheme of exergy transformations, that occur in the basic and alternative schemes, is shown in Figure 3.

According to this methodology, during comparing circuit solutions the main indicator is the exergy efficiency value $\varepsilon_{i n}$ :

$$
\varepsilon_{\text {in }}=E_{p} / E_{F},
$$

where $E_{P}$ - system exergy of the product stream; $E_{F}-$ system exergy of the fuel stream.

A value difference $E_{F}$ and $E_{P}$ gives a destruction value $E_{D}$ and exergy losses $E_{L}$ in the energy transformation processes of the system, that is

$$
E_{D}+E_{L}=E_{F}-E_{P} .
$$

It should be noted that $E_{D}$ value characterizes the level of dissipative losses due to internal irreversibility, and $E_{L}$ is due to the presence of external heat exchange of system components with the environment.

When we use this type of the exergy analysis does not require an entropy analysis to calculate the total destruction and loss of exergy in the system, as follows from equation (1).
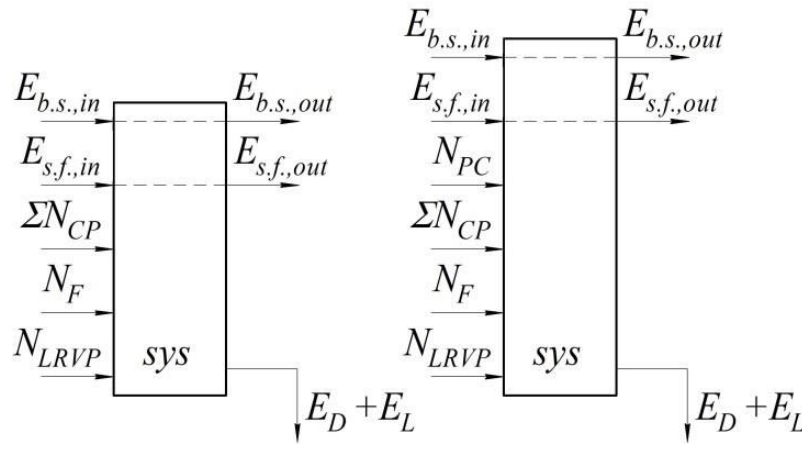

Figure 3 - The scheme of exergy transformations in the basic (a) and alternative (b) schemes

In determining $E_{P}$ and $E_{F}$ for the vacuum systems under consideration, some assumptions have been made to make significant simplifications in the calculations, namely:

- condensate flows that are removed from the system to the environment after the condensation pumps, taking into account their further non-use as energy sources, are classified as exergy losses;

- a similar approach is adopted for the mixture flows at the outlet from E3 ejector for the basic scheme and at the outlet of the liquid separator according to an alternative scheme;

- the heat flux, which is transmitted to the environment after the cooling tower is also classified as exergy losses;

- the change in the exergy of air leaks is neglected.

Taking into account the above assumptions for the basic scheme, we have:

$$
\begin{gathered}
E_{P 1}=\dot{m}_{s . f .}\left(e_{s . f . \text { out }}-e_{s . f . \text { in }}\right) \\
E_{F 1}=\left(\dot{m}_{\text {b.s. }}\right)_{e} \cdot e_{b . s . \text { in }}+\sum N_{C P}+N_{F}+N_{L R V P} .
\end{gathered}
$$

For the scheme with LVE: 


$$
\begin{gathered}
E_{P 2}=\dot{m}_{s . f .}\left(e_{s . f ., \text { out }}-e_{s . f . \text { in }}\right) \\
E_{F 2}=\left(\dot{m}_{\text {b.s. }}\right)_{H} \cdot e_{\text {b.s. } H}+N_{P C}+\sum N_{C P}+N_{F}+N_{L R V P},
\end{gathered}
$$

where $\dot{m}_{s . f}$. - mass flow rate of the secondary flow, $\mathrm{kg} / \mathrm{s} ;\left(\dot{m}_{b . s .}\right)_{e}-$ a total mass flow rate of boiler steam to the base circuit ejectors, $\mathrm{kg} / \mathrm{s} ;\left(\dot{m}_{b . s .}\right)_{H}$ - a mass flow rate of boiler steam through the circulation flow heater, $\mathrm{kg} / \mathrm{s}$; $e_{\text {s.f.in }}, e_{\text {s.f.,out }}-$ specific exergy of secondary flow under the conditions of inlet and outlet in the vacuum system, $k J / k g ; e_{b . s . \text {,in }}-$ specific exergy of boiler steam at the ejector inlet in the basic scheme, $\mathrm{kJ} / \mathrm{kg} ; e_{b . s . H}-$ specific exergy of boiler steam at the entrance to the heater circuit based on the liquid-vapor ejector, $\mathrm{kJ} / \mathrm{kg} ; \sum N_{C P}-$ total power consumption of coolant pumps, $\mathrm{kW} ; N_{P C}$ - power consumption of circulating circuit pump, that is based on the liquid-vapor ejector, $\mathrm{kW} ; N_{F}-$ a power consumption of cooling tower fan, $k W ; N_{L R V P}-$ a power consumption of liquid ring vacuum pump, $\mathrm{kW}$.

After the exergy transformation of these values for the basic scheme, we obtain:

$$
\begin{aligned}
& E_{P 1}=\dot{m}_{s . f .} \cdot\left[\begin{array}{l}
\tilde{c}_{p} \cdot\left(T_{s . f ., \text { out }}-T_{\text {s.f.,in }}\right)- \\
-T_{\text {env. }} \cdot\left(\tilde{c}_{p} \cdot \ln \frac{T_{s . f . \text { out }}}{T_{\text {s.f.,in }}}-R \cdot \ln \frac{P_{\text {s.f.,out }}}{P_{\text {s.f.,in }}}\right)
\end{array}\right], \\
& E_{F 1}=\left(\dot{m}_{\text {b.s. }}\right)_{e} \cdot\left[\left(h_{\text {in }}-h_{\text {out }}\right)-T_{\text {env. }} \cdot\left(s_{\text {in }}-s_{\text {out }}\right)\right]+. \\
& +\sum N_{C P}+N_{F}+N_{L R V P}
\end{aligned}
$$

For the scheme, which is based on the liquid-vapor ejector:

$$
\begin{aligned}
& E_{P 2}=\dot{m}_{s . f .} \cdot\left[\begin{array}{l}
\tilde{c}_{p} \cdot\left(T_{s . f . \text { out }}-T_{\text {s.f.,in }}\right)- \\
-T_{\text {env. }} \cdot\left(\tilde{c}_{p} \cdot \ln \frac{T_{s . f ., \text { out }}}{T_{\text {s.f.,in }}}-R \cdot \ln \frac{P_{s . f ., \text { out }}}{P_{\text {s.f.,in }}}\right)
\end{array}\right], \\
& E_{F 2}=\left(\dot{m}_{\text {b.s. }}\right)_{H} \cdot\left[\left(h_{\text {in }}-h_{\text {out }}\right)-T_{\text {env. }} \cdot\left(s_{\text {in }}-s_{\text {out }}\right)\right]+\text {. } \\
& +N_{P C}+\sum N_{C P}+N_{F}+N_{L R V P}
\end{aligned}
$$

where $\tilde{c}_{p}-$ specific heat of passive flow at medium temperature $\frac{T_{\text {s.f.,in }}+T_{\text {s.f.,out }}}{2}, \mathrm{~kJ} /(\mathrm{kg} \cdot \mathrm{K}) ; \mathrm{T}_{\text {s.f., in }}-$ temperature of the secondary flow at the inlet of the ejector of the 1st degree of the base circuit and the heat exchanger-heater circuit, which is based on LVE, K; $T_{\text {s.f., out }}$ - secondary flow temperature at the condenser outlet after the liquid ring vacuum pump, $\mathrm{K} ; T_{\text {env. }}-$ ambient temperature, $\mathrm{K} ; R$ - gas specific matter of secondary flow, $\mathrm{kJ} /(\mathrm{kg} \cdot \mathrm{K}) ; P_{\text {s.f., in }}-$ secondary flow pressure at the ejector inlet, $\mathrm{Pa} ; P_{\text {s.f., out }}-$ secondary flow pressure at the condenser outlet after the liquid-ring vacuum pump, $\mathrm{Pa}$; $h_{\text {in }}$ - boiler steam enthalpy at the ejector inlet of the 1 st degree on the basic scheme and the heat exchanger-heater of the scheme with LVE, $\mathrm{kJ} / \mathrm{kg} ; h_{\text {out }}$ - boiler steam enthalpy at the ejector outlet of the 3rd degree on the basic scheme and the heat exchanger-heater of the scheme with $\mathrm{LVE}, \mathrm{kJ} / \mathrm{kg} ; s_{\text {in }}$ - boiler steam entropy at the ejector inlet of the 1st degree on the base circuit and the heat exchanger-heater circuit, that is based on LVE, $\mathrm{kJ} /(\mathrm{kg} \cdot \mathrm{K})$; $s_{\text {out }}$ - boiler steam entropy at the ejector outlet of the $3 \mathrm{rd}$ degree on the basic scheme and the heat exchanger-heater of the scheme with $\mathrm{LVE}, \mathrm{kJ} /(\mathrm{kg} \cdot \mathrm{K})$.

To assess the economic effect of the new technology introduction, it is necessary to perform a thermoseconomical calculation, which is determined the cost of fuel that is required for the basic and energy-saving scheme.

For the basic fuel scheme is used superheated steam boiler and electricity, which are needed to drive the coolant pump, vacuum pump and cooling tower fan so the total fuel cost is determined by the formula:

$$
\begin{aligned}
C_{b a s} & =C_{b . s . \text { bas }}+C_{e l e, \text { бas }}=c_{b . s .} \cdot\left(\dot{m}_{b . s .}\right)_{e} \cdot \tau_{p}+ \\
& +c_{e l e} \cdot\left(\sum N_{C P}+N_{F}+N_{L R V P}\right) \cdot \tau_{p}
\end{aligned},
$$

where $c_{K . n .}-$ cost of boiler superheated vapor, $\mathrm{UAH} /(\mathrm{kW} \cdot \mathrm{h}) ; \tau_{p}$ - calculation period of the unit operation, h; $c_{e / e}$ - electricity cost for Ukrainian industrial enterprises $\mathrm{UAH} /(\mathrm{kW} \cdot \mathrm{h})$.

For the energy-saving scheme a fuel cost is determined as follows:

$$
\begin{gathered}
C_{L V E}=C_{b . s ., L V E}+C_{e l e, L V E}=c_{b . s .} \cdot\left(\dot{m}_{b . s .}\right)_{H} \cdot \tau_{p}+ \\
+c_{e l e} \cdot\left(N_{P C}+\sum N_{C P}+N_{F}+N_{L R V P}\right) \cdot \tau_{p}
\end{gathered}
$$

The economic effect of a new vacuum cooling system introduction in the biodiesel production unit is:

$$
E=C_{b a s}-C_{L V E}, U A H
$$

The specific price per unit of product $(\mathrm{kg})$ for the basic and alternative scheme is determined by the formulas:

$$
\begin{gathered}
p_{G, b a s}=\frac{C_{\text {bas }}}{\dot{m}_{s . f .} \cdot \tau_{p}}, U A H / k g, \\
p_{G, P I I E}=\frac{C_{L V E}}{\dot{m}_{s . f .} \cdot \tau_{p}}, U A H / k g .
\end{gathered}
$$

\section{Results and Discussion}

Calculation results of regime and energy parameters by comparative schemes are given in Table 1, exergy indicators - in Table 2. 
Table 1 - Regime and energy parameters of the circuit solution variants

\begin{tabular}{|l|c|c|}
\hline \multicolumn{1}{|c|}{ Parameter } & \multicolumn{2}{|c|}{ Design scheme } \\
\cline { 2 - 3 } & basic & $\begin{array}{c}\text { with } \\
\text { LVE }\end{array}$ \\
\hline $\begin{array}{l}\text { Initial pressure in the vacuum } \\
\text { system, kPa }\end{array}$ & 5 & 5 \\
\hline $\begin{array}{l}\text { Pressure suction of vacuum } \\
\text { pump, } \mathrm{kPa}\end{array}$ & 40 & 40 \\
\hline Boiler vapor pressure, $\mathrm{kPa}$ & 900 & 900 \\
\hline Boiler vapor temperature, ${ }^{\circ} \mathrm{C}$ & 180 & 180 \\
\hline $\begin{array}{l}\text { Mass flow rate of boiler vapor, } \\
\mathrm{kg} / \mathrm{h}\end{array}$ & 1535 & 215 \\
\hline $\begin{array}{l}\text { Mass flow rate of secondary flow, } \\
\mathrm{kg} / \mathrm{h}\end{array}$ & 213 & 213 \\
\hline $\begin{array}{l}\text { Volume flow rate of a coolant, } \\
\mathrm{m}^{3} / \mathrm{h}\end{array}$ & 223 & 109 \\
\hline Mass flow rate of a coolant, kg/h & $2.2 \cdot 10^{5}$ & $1.1 \cdot 10^{5}$ \\
\hline $\begin{array}{l}\text { Power consumption of a coolant } \\
\text { pump, } \mathrm{kW}\end{array}$ & 6.5 & 3.2 \\
\hline $\begin{array}{l}\text { Power consumption of the pump } \\
\text { circulation loop, } \mathrm{kW}\end{array}$ & - & 0.1 \\
\hline $\begin{array}{l}\text { Power consumption of the vacu- } \\
\text { um pump, } \mathrm{kW}\end{array}$ & 4.0 & 4.0 \\
\hline $\begin{array}{l}\text { Power consumption of the cool- } \\
\text { ing tower fan, } \mathrm{kW}\end{array}$ & 3.15 & 2.1 \\
\hline
\end{tabular}

Table 2. Exergy indexes of schematic variants

\begin{tabular}{|l|c|c|}
\hline \multirow{2}{*}{\multicolumn{1}{|c|}{ Parameter }} & \multicolumn{2}{c|}{ Design scheme } \\
\cline { 2 - 3 } & basic & $\begin{array}{c}\text { with } \\
\text { LVE }\end{array}$ \\
\hline $\begin{array}{l}\text { Exergy of a product flow, } \\
\mathrm{kW}\end{array}$ & 24.5 & 24.5 \\
\hline Exergy of a fuel flow, $\mathrm{kW}$ & 336.3 & 55.6 \\
\hline Exergy efficiency & 0.073 & 0.441 \\
\hline
\end{tabular}

On the basis of the software package for calculating the vacuum unit, which was developed by the author, calculations were performed to assess the impact of the increasing degree in the passive flow pressure with LVE on the injection coefficient and exergy efficiency indicators. On Figure 4 this dependence is presented, allowing the choice of intermediate pressure between compression stages for the vacuuming system.

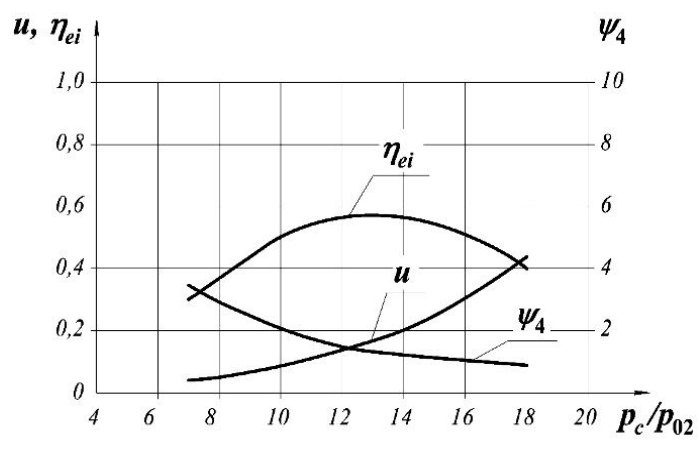

Figure 4 - The dependence graph of the degree of vapor overproduction $\psi_{4}$, injection coefficient $\mathrm{u}$ and exergy efficient $\eta_{\mathrm{ei}}$ from the increasing value of the passive flow pressure $\mathrm{p}_{\mathrm{c}} / \mathrm{p}_{02}$ at $t_{01}=121-149{ }^{\circ} \mathrm{C}, p_{01}=300-500 \mathrm{kPa}, p_{02}=5 \mathrm{kPa}$

\section{Conclusions}

As a result, during the comparative calculation of the evacuation schemes on the basis of a three-stage steamjet ejector and a liquid-vapor ejector, it can be concluded, if we use LVE, we can make it possible to increase the efficiency of the biodiesel production unit as follows:

- to simplify the design of the installation by switching from a two-stage steam-jet ejector to a single-stage vacuum unit, based on LVE.

- to reduce the initial parameters of the working vapor by switching to more moderate parameters of the working fluid in the active flow with LVE (from 9 bar and $225^{\circ} \mathrm{C}$ to 4 bar and $135^{\circ} \mathrm{C}$ ) and to minimize the consumption of this vapor due to the design features of the vacuum unit, based on LVE, in which the working vapor is consumed not as an active flow of the steam-jet ejector, but only in a small amount for heating the working fluid of the active flow in the heat exchanger-heaters (a vapor reduction).

According to the results of the exergy analysis, we see that the energy efficiency of the vacuum cooling system in the biodiesel production unit, that is based on the liquid-vapor ejector is more than 6 times higher than for the basic scheme.

More accurate optimization of the vacuum system was carried out on the basis of thermo-economic analysis by Tsatsaronis method considering the economic model for the optimization indicator in the value form of the exergy product cost and found, that the fuel cost for the basic scheme is $101797 \mathrm{UAH}$, and for energy saving $64578 \mathrm{UAH}$, it follows that the economic effect of the new scheme introduction is $37219 \mathrm{UAH}$.

\section{References}

1. Sharapov, S. O., Arsenyev, V. M., \& Kozin, V. M. (2017). Application of jet thermal compression for increasing the efficiency of vacuum systems. IOP Conference Series: Materials Science and Engineering, Vol. 233, 012028.

2. Sharapov, S. O. (2011). Problems of experimental studies of liquid-vapor ejector working process in the vacuum regime and their technical content. Bulletin of Sumy State Univerity. Series "Technical Sciences", Vol. 1, pp. 51-57.

3. Sharapov, S., \& Arsenyev, V. (2016). Experimental study of a liquid-vapor ejector with a cylindrical mixing chamber. Refrigerating Equipment and Technology, Vol. 52(2), pp. 87-92.

4. Sharapov, S., Arsenyev, V., \& Kozin, V. (2016). Experimental investigation of liquid-vapor ejector with conical mixing chamber. Technology Audit Production Reserves, Vol. 4, No. 1(30), pp. 50-55. 
5. Sharapov, S., Arsenyev, V., \& Protsenko, M. (2013). The use of liquid-vapor ejector in vacuum systems. Science et Tchnique du Foid - Refrigeration Science and Technology, Vol. 4.

6. Tsatsaronis, J. (2002). The interaction of thermodynamics and economics to minimize the cost of energy-conversion system. Negotiant Studio Ltd., Odessa, Ukraine.

7. Morozyuk, T. V. (2006). Theory of cooling and heat pumps. Negotiant Studio Ltd., Odessa, Ukraine

8. Arsenyev, V. M. (2011). Heat pump energy conservation technology. Sumy State University, Sumy, Ukraine.

\author{
Удосконалення вакуумної системи охолодження \\ установки виробництва біодизельного палива \\ Шарапов C. ${ }^{1}$, Старченко M. ${ }^{1}$, Проценко М. ${ }^{2}$, Панченко В. ${ }^{1}$, Ковтун В. ${ }^{1}$ \\ ${ }^{1}$ Сумський державний університет, вул. Римського-Корсакова, 2, 40007, м. Суми, Україна; \\ ${ }^{2}$ Академія управління та адміністрування м. Ополє, вул. М. Нєдзяловського, 18, 46020, м. Ополє, Польща
}

\begin{abstract}
Анотація. У статті вирішено актуальну проблему підвищення ефективності вакуумних систем охолодження установок виробництва біодизельного палива шляхом застосування вакуумних агрегатів на базі рідинно-парового ежектора, що працює за принципом струминної термокомпресії. Метою даного дослідження $є$ підтвердження доцільності застосування вакуумних агрегатів на базі рідинно-парового ежектора, що працює за принципом струминної термокомпресії, у вакуумних системах охолодження установок виробництва біодизельного палива. Подано опис базової схеми системи охолодження установки виробництва біодизельного палива, яка містить трьохступеневий пароструминний ежектор. Запропоновану схему на базі рідинно-парового ежектора. Виконано порівняльний аналіз вакуумних систем охолодження установок виробництва біодизельного палива, схеми яких порівнювались, у тому числі на базі існуючих триступеневих пароструминних ежекторів і нового одноступеневого вакуумного агрегату на базі рідиннопарового ежектора. Як порівняльний аналіз застосовано ексергетичний метод оцінювання ефективності застосування запропонованого устаткування, оскільки у робочому процесі відбувається перетворення двох видів енергії: електричної (для приводу насоса) і теплової (для підігріву робочої рідини активного потоку у теплообміннику-підігрівачі). У результаті досягнуті більші показники ефективності застосування нової технології за оптимізаційним параметром - проміжним тиском між рідинно-паровим ежектором та рідиннокільцевим вакуумним насосом.
\end{abstract}

Ключові слова: вакуумна система охолодження, рідинно-паровий ежектор, біодизельне паливо, ексергетичний коефіцієнт корисної дії. 